\title{
MARJINALISASI (PUBLIK) AKTIVIS DALAM LITERATUR PUBLIC RELATIONS
}

\author{
Nurhidayati Kusumaningtyas \\ Balai Diklat Industri Yogyakarta \\ n_kusumaningtyas@yahoo.com
}

\begin{abstract}
Activism can involve an individual or a collection of a few people. The practice of activism is often perceived as negative and destructive actions. In the literature of public relations, we will discover how the activist group pressure group categorized into the "source of trouble" and must be addressed by public relations practitioners. This perspective led to a bias that leads to marginalization of "activist public" in public relations literature. Marginalization process lasts through two methods: (1) the provision of which tend negative stigma, (2) the dominance of the paradigm of "corporate centric" in the literature of public relations. This article presents an alternative paradigm of the postmodern paradigm in view of the role and functions of the public activists.
\end{abstract}

\begin{abstract}
Abstrak
Aktivisme bisa melibatkan seorang individu ataupun kumpulan beberapa orang. Praktek aktivisme seringkali dipersepsikan sebagai tindakan yang negatif dan destruktif. Dalam literatur public relation, kita akan menemukan bagaimana kelompok aktivis dikategorikan kedalam kelompok penekan yang menjadi "sumber masalah" dan harus diatasi oleh praktisi public relations. Perspektif ini memunculkan bias yang mengarah pada marjinaliasi "publik aktivis" dalam literature public relation. Proses marjinalisasi berlangsung melalui dua cara: (1) pemberian stigma yang bertendensi negative, (2) adanya dominasi paradigma "corporate centric" dalam literatur public relation. Artikel ini menyajikan alternatif paradigma yakni paradigma postmodern dalam melihat peran dan fungsi publik aktivis.
\end{abstract}

Keywords: Public Activist, Corporate Centric, Marginalization.

\section{PENDAHULUAN}

Seorang perempuan berusia 23 tahun bertahan diatas pohon California Redwood dengan ketinggian mencapai 18o kaki selama 738 hari memprotes penebangan pohon yang dilakukan oleh perusahaan Pacific Lumber Company. Perempuan tersebut menyatakan tidak akan turun dari pohon hingga perusahaan tidak menebang pohon di ketiga area khusus. Kasus lainnya adalah kasus David Vs Goliath dimana seorang pekerja pos dan tukang kebun yang bekerja paruh waktu diajukan ke persidangan oleh perusahaan besar Mc Donald dengan tuduhan keduanya (bersama beberapa rekannya) menyebarkan leafletyangmengkritik perusahaan berskala multi billion dollar dengan menyebutkan perusahaan tersebut telah menekan upah karyawan dan menyedikan makanan yang tidak sehat.

Persidangan kedua orang tersebut menjadi rekor pengadilan dengan waktu terlama dalam sejarah pengadilan Inggris dan akhirnya hakim memutuskan Mc Donalds harus membayar 60.0oo poundsterling dan mengakui beberapa informasi yang terdapat dalam leaflet benar adanya. Dari kasus tersebut, secara nyata Mc Donald harus kehilangan 
materi sekaligus menghabiskan waktu para eksekutifnya untuk memberikan keterangan di depan pengadilan dan yang paling buruk adalah Mc Donald kehilangan reputasinya.

Ilustrasi kisah diatas merupakan salah satu contoh tindakan aktivisme.Aktivisme bisa melibatkan seorang individu ataupun kumpulan beberapa orang. Sebagaimana kisah diatas aktivisme bisa dijalankan oleh seorang perempuan ataupun dua orang yang "lemah" yang dapat mempengaruhi korporasi untuk mengubah kebijakannya.

Praktek aktivisme seringkali dipersepsikan sebagai tindakan yang negatif dan destruktif. Bila menyimak sejarah aktivisme dalam bentuk gerakan sosial yang terjadi di duniaseperti pada era 1880an yang mengemukakan isu mengenai animal rights, kemudian era 1960an dan 1970an aktivisme tumbuh subur melalui pergerakan sosial yang mengusung tema mengenai feminisme, environmentalisme, dan banyak isu lainnya. Kemudian dalam konteks Indonesia sendiri aktivisme melalui pergerakan sosial berhasil mengangkat isu mengenai kesetaraan jender, kebebasan berekspresi, dan perlindungan ketenagakerjaan.Praktek itu mendorong "keadilan baru" dalam kehidupan sosial.

Munculnya wacana-wacana di atas yang didorong oleh aktivisme ternyata memberikan kontribusi positif bagi perubahan sosial politik di banyak negara.Jadibukankah tindakah aktivisme juga memberikan kontribusi positif bagi masyarakat? Namun bila kita menyimak studi-studi mengenai aktivisme dalam literature public relations, kita akan menemukan perspektif bahwa tindakan aktivisme adalah tindakan yang destruktif dan membahayakan bila tidak segera ditangani. Tendensi tersebut dapat disimak melalui penamaan publik aktivis sebagai "pressure group". Pemberian stigma negatif tersebut dikhawatirkan memunculkan bias persepsi yang mengarah pada marjinalisasi publik aktivis. Dengan latarbelakang tersebut, tulisan ini bertujuan untuk menelaah bagaimana marjinalisasi berlangsung, serta memberikan alternatif adanya pendekatan postmodern dalam melihat peran dan fungsi publik aktivis.

\section{PEMBAHASAN}

\section{Pemberian Stigma Negatif Publik Ak- tivis dalam Literatur Public Relation}

Marjinalisasi berlangsung dengan menciptakan stigma negatif terhadap kelompok aktivis dan sebaliknya membangun stigma positif terhadap public relations.Aktivisme seringkali dipersepsikan sebagai“sumber masalah" dan public relations sebagai representasi organisasi atau korporasi sebagai pihak yang memiliki solusi yang dengan strateginya berusaha mengatasi "sumber masalah".

Sebagai ilustrasi dalam sebuah drama sering kita mengenal peran protagonis dan antagonis. Peran protagonis mencerminkan persepsi yang positif sementara sebaliknya peran antagonis mencerminkan peran negatif yang menganggu dan harus diatasi. Bila dalam drama, peran antagonis mutlak menjalankan aktivitas dengan stigma negatif yang destruktif.Sebaliknya bila menyimak di bidang bio-chemistry, antagonistik justru merupakan tindakan yang memunculkan hasil yang positif. Antagonistik dalam bio-chemistry bertugas untuk melawan dan mengurangi unsur-unsur kimia dalam tubuh. Insulin misalnya, berfungsi untuk mengurangi kadar glukosa dalam darah manusia. Jadi, antagonis tidak selalu mutlak berperan negatif atau destruktif sebagaimana dalam sebuah drama.Memiliki peran antagonis bisa jadi justru berpengaruh positif dan membangun sistem kearah yang lebih baik.

Dalam literatur public relations, aktivisme dikonstruksikan sebagai kelompok antagonis dengan stigma yang negatif.Dougall (2005) menyebutkan activists are predominantly treated as a hostile part of the organization's environment in the public relationss research and literatur. (Aktivis kerapkali diperlakukan sebagai bagian yang dimusuhi oleh organisasi dalam penelitian dan literatur publik relation).

Grunig (1992) juga mengakui hubungan antara organisasi dan publik aktivis kerap digambarkan sebagai antipati dimana kelompok itu dilihat sebagai pembuat masalah 
yang memiliki koneksitas yang rendah dengan organisasi (baca: korporasi). Permusuhan antara organisasi dan pressure group sebagai sebuah kelaziman yang jamak ditemui dalam literatur dan penelitian public relation.

Artikel Larissa Grunig yang bertajuk "Activism: How It Limits Effectiveness Organization and How Excellence Public relations Department Respond" juga bisa menjadi sebuah contoh bagaimana stigma negatif diberikan kepada publik aktivis. Dari judul artikel tersebut sudah memperlihatkan bahwa aktivis ditempatkan sebagai pihak antagonis yang menjadi masalah dan menimbulkan inefisiensi dalam organisasi. Artikel itu sekaligus menempatkan publik relations sebagai pihak protagonis dengan menyebutkan public relations sebagai pihak yang "excellence" dalam mengatasi "aksi" kelompok aktivis.

Pada bagian penjelasan dalam artikelnya tersebut Grunig menyebutkan kelompok aktivis menciptakan inefisiensi organisasi yang membahayakan otonomi organisasidan menimbulkan ekonomi biaya tinggi, menurunkan pangsa pasar, dan merusak reputasi. Oleh karenanya korporasi atau organisasi harus mengatasi "masalah aktivis" untuk menjaga otonomi organisasi/korporasi. Pandangan yang dikemukakan oleh Grunig tersebut rupanya mendominasi banyak literatur public relations.

Marjinalisasi peran aktivis sebagai kelompok antagonis dengan stigma negatif juga ditunjukkan melalui pemberian definisi yang timpang makna. Seperti definisi yang dikembangkan oleh Grunig. Ia mendefinisikan aktivis sebagai a group of two or more individuals who organize in order to influence another public or publics through action. Menurut Coombs dan Holliday kata "influence" sendiri memiliki makna pada relasi kekuasaan yang tidak seimbang. Influence merupakan tipe kekuasaan ketika salah satu konstituensi dapat mengubah perilaku konstituensi lainnya. Sangat jarang ditemui dua pihak yang memiliki kedudukan yang sama dalam kuasa (power)/pengaruh (influence). Kelompok aktivis disini ditempatkan sebagai kelompok yang selalu ingin menggerogoti kekuasaan organisasi dengan tindakan-tindakan yang destruktif. Grunig dengan jelas menyebutkan "activist pressure is an extensive problem for organization"

\section{Munculnya Dominasi Corporate Centric dalam Literatur Public Relations}

Stigma negatif dalam penelitian dan literatur public relations yang terus berkembang mulai mengarah pada marjinalisasi publik aktivis. Beberapa studi kritis yang melihat adanya marjinalisasi publik aktivis dapat ditemukan dalam studi yang dilakukan oleh Dozier dan Lauzen, Coombs dan Holiday, serta Mc Kie dan Munshi. Dozier dan Lauzen melihat adanya"deep pocket bias" dalam literatur public relations ketika relasi antara publik aktivis dengan organisasi. Lebih lanjut Dozier dan Lauzen menyebutkan studi yang telah ada mengenai hubungan antara organisasi dan aktivis lebih didominasi peran-peran praktisi public relations sebagai representasi organisasi dalam menjalankan fungsinya.Dozier dan Lauzen melihat dominasi ini dengan istilah "organization centric".

Sementara itu menurut Coombs dan Holliday, kajian public relations selama ini dikooptasi oleh pandangan "corporate centric". Corporate centric yakni sebuah pandangan yang menempatkan public relations sebagai alat untuk mencapai kesuksesan ekonomi.

Mc Kie dan Munshi (2007) juga menyebutkan adanya kesenjangan studi oleh para akademisi yang memunculkan dominasi pandangan yang cenderung corporate centric (Coombs and Hoolliday, 2010). Kedua istilah di atas- "organization centric" dan "corporate centric"-menggambarkan adanya dominasi pemaknaan public relations oleh korporasi/ institusi.

Bila menyimak kembali literatur pada bidang keilmuan public relations, harus diakui bahwa selama ini, paradigma yang berkembang dalam literatur public relations adalah paradigma positivis-fungsionalis yang bias pada praktek-praktek public relations sebagai representasi organisasi (korporasi). Paradigma positivis-fungsionalis inilah yang 
"berkuasa" dalam banyak literatur public relations.

Implikasi dari dominasi paradigma positivis-fungsionalis adalah sedikitnya literatur yang membahas mengenai kontribusi positif publik aktivis bagi organisasi (korporasi). Mc Kie dan Munshi mengkritik kurangnya studi mengenai peran aktivis dan kontribusinya terhadap public relations dan organisasi yang menyebabkan marjinalisasi persepsi aktivis. Kalaupun ada riset mengenai aktivis, tetap saja pendekatan yang digunakan organization centric.Sementara itu menurut Curtin dan Gaither (2005) riset tentang aktivispun lebih memfokuskan pada perannya dalam perspektif organisasi (corporate centric) yang menempatkan aktivis sebagai target perubahan.

Literatur public relations selama ini telah mengabaikan peran dan fungsi publik aktivis sebagai agen perubahan masyarakat sebagaimana muncul pada era progresif.Literatur public relations bahkan melupakan bagaimana dahulu public relations pernah "mengkooptasi" tehnik-tehnik yang dikembangkan oleh kelompok aktivis.

Stigma negatif terhadap publik aktivis oleh praktisi dan akademisi public relations tidak bisa dilepaskan dari konteks sejarah munculnya public relations. Pada masa awal perkembangan public relations, studi mengenai aktivisme pun sudah marjinal. Hal tersebut tertuang dalam buku yang bertajuk Public relations History from the $17^{\text {th }}$ to the $2 \mathrm{O}^{\text {th }}$ Century: The Antecendent. Dalam buku tersebut disebutkan bahwa: Activist activities are viewed as related to public relationss but only as antecedents and not necessarily part of its corpus.

Kemudian dalam perkembangannya, sejarah mencatat relasi antara aktivis dengan organisasi selalu diwarnai dengan konflik frontal. Konflik pertama kali antara publik aktivis dengan organisasi yang tercatat dalam sejarah terjadi pada tahun 1884 , ketika American Medical Association mengusung isu antivivisectionist, yang menjadi embrio pergerakan animal rights.

Konflik antara organisasi dan publik ak- tivis semakin sering terjadi pada era 1960an dan 1970an yang kemudian dikenal dengan "the progresive era".Era ini menandai tumbuh suburnya pergerakan sosial yang kemudian menjadi katalis tumbuhnya public relations.Korporasi mulai melirik menggunakan praktisi public relations professional untuk mengatasi berbagai tuntutan kelompokkelompok aktivis. Sejarahnya, tujuan aktivis selalu berbenturan dengan tujuan korporasi. Para "muckrakers" pada awal 1990 menginginkan adanya perubahan kebijakan publik organisasi yang membawa konsekuensi lebih banyak uang yang harus dikeluarkan oleh korporasi. Hubungan yang kurang harmonis dalam berbagai peristiwa dari waktu ke waktu bahkan hingga saat ini, menjadi salah satu alasan kuatnya stigma negatif terhadap publik aktivis.

\section{Pendekatan Postmodern sebagai Alter- natif dalam Melihat Publik Aktivis}

Dougall melakukan sebuah penelitian untuk melihat relasi organisasi dan aktivis melalui aliran informasi diantara keduanya yang muncul dalam publikasi di media dari tahun 1980-2001. Dengan menggunakan analisis konten terhadap 6500 artikel diperoleh hasil bahwa persepsi terhadap aktivis memiliki tendensi antagonistik. Dengan menggunakan model penelitian longitudinal, Dougall mampu memotret adanya perubahan atau pergeseran relasi antara aktivis dan organisasi.

Hal serupa juga dikemukan oleh Dozier yang menyebutkan bahwa terjadi perubahan selama lebih dari 20 tahun dalam keilmuan public relation khususnya dalam cara melihat publik aktivis. Dozier dan Lauhan dalam Journal of Public RelationsResearchmemberikan dorongankepada para akademisi untuk mempertimbangkan keunikan kelompok aktivis dan pergerakan sosial sebagai pelaku public relation yang menghubungkan antara korporasi dengan khalayak.

Bila melihatliteratur public relations sejak awal berkembang, dapat dikatakan bahwa disiplin ilmu public relationshampir didominasi oleh paradigma positivis-fungsionalis 
yang diusung oleh akademisi seperti James Grunig, Larissa Grunig, dan kawan-kawan. Sebagaimana ditegaskan oleh Botan dan Hazleton (2009) dalam Public Relations Theory II, menyebutkan bahwa Excellence Theory merupakan paradigma dominan yang menguasai dalam literatur dan penelitian public relations yang kemudian menjadi semacam ortodok terhadap pemikiran-pemikiran lainnya. Paradigma "excellence theory" didominasi oleh para pemikir Amerika. Paradigma dominan ini mencoba mengkooptasi istilah seperti persuasi, advokasi, dan aktivisme.

Baru menjelang tahun zoooan mulai muncul pendekatan-pendekatan kritis yang diusung oleh tokoh-tokoh seperti Dozier dan Lauzen, Berger, Dougall, Holtzhausen\& Voto. Pendekatan kritis inijuga sering disebut dengan pendekatan postmodern. Mc Kie (2005) mencatat bahwa munculnya telaah kritis terhadap literatur public relations mengacu pada teori kritis yang dikemukakan oleh filosof dari Eropa yang peduli pada isu kekuasaan dan penindasan yang terjadi dalam masyarakat. Paradigma kritis inilah yang kemudian dikenal sebagai paradigma postmodern.

Ketika para penganut "excellence theory" menetapkan definisi public relation yang bias makna maka Coombs dan Holladay (2010) menawarkan definisi baru mengenai public relations yang menyebutkan bahwa "public relations as the management of mutually influential relationships within a web of constituency relationships". Melalui definisi ini Coombs ingin menawarkan relasi yang lebih berimbang, praktik public relation ditujukan untuk membangun hubungan baik dan bukan hanya berkutat pada taktik-taktik yang manipulatif.

Para penganutpostmodern juga melihat peluang positif akan keberadaan aktivis. Dalam pandangan postmodern, aktivis tidak semuanya memiliki pandangan yang radikal. Beberapa aktivis secara tegas memang memiliki pandangan yang ekstrem yang menuntut perubahan mendasar dan menggunakan strategi-strategi yang militan seperti sabotase.Kovacs dalam studi terhadap enam kelompok aktivis di Inggris yang melihat strategi komunikasi dan bagaimana mereka mengelola hubungan menunjukkan bahwa kelompok aktivis tersebut tidak semuanya menunjukkan cara-cara yang konfrontatif. Jadi mengeneralisir public aktivis sebagai publik yang radikal adalah tidak tepat.

Publik aktivis meskipun menjalankan peran antagonis, mereka memberikan pengaruh positif dalam perubahan sosial. Misalnya, beberapa pergerakan sosial yang didorong oleh para aktivis berhasil mengakhiri perbudakan, memunculkan hak-hak perempuan dalam politik, mengakhiri apartheid di Afrika Selatan, dan mendorong produksi makanan yang sehat. Melalui contoh itu, dapat disimpulkan bahwa menjadi antagonis tidak berarti negatif.

Bahkan bagi perkembangan keilmuan public relations, publik aktivis juga secara nyata berkontribusi positif. Studi yang dilakukan oleh Taylor, et.al (2001) menunjukkan bagaimanapublic relations terinspirasi-atau dalam bahasa yang lebih kritis, mengkooptasi-strategi dan tehnik yang dikembangkan oleh publik aktivis.

Taylor melihat bahwa berbagai macam saluran didalam internet telah dimanfaatkan oleh publik aktivis untuk mempengaruhi praktek-praktek korporasi.Penggunaan internet oleh publik aktivis kemudian direspon oleh publik relation dengan "mengkooptasi" tehnik-tehnik yang dikembangkan oleh public aktivis.Kini kita mendengar bagaimana digital spesialis menjadi sangat dibutuhkan dalam bidang publik relations dalam menjalankan fungsinya.

Menurut Coombs (2002) aktivis merupakan kelompok yang pertama kali menggunakan sosial media dan surat elektronik. Mereka berpandangan bahwa internet lebih murah dan cepat dalam membangun komunikasi. Sekarang kita bisa melihat bagaimana korporasi "mengkooptasi" penggunaan berbagai macam jejaring sosial dan surat elektronik sebagai bagian dari kegiatan publik relations yang dijalankan oleh korporasi.

Sementara itu dalam studi yang dilakukan oleh Holtzhausen\& Voto (2002) dan Berger (2005) tindakan-tindakan aktivisme 
justru mendorong organisasi untuk mempertimbangkan pengambilan keputusan yang berlandaskan etika.Grunig (1997), meskipun secara umum dirinya merupakan pengusung pendekatan positivis-fungsionalis, pada bagian tertentu juga mengakui pentingnya peran aktivis bagi organisasi.

Grunig mengatakan aktivisme menjadi hal penting bagi public relations karena organisasi akan kehilangan nilai-nilai tanpa kehadiran kelompok aktivis. With relationship management at the nexus of contemporary public relationss practice, the relationships organizations have with their activist publics are important for both public relationss practitioners and scholars (Botan \& Taylor, 2004; Dozier \& Lauzen,200o; Grunig, 2001; Holtzhausen, 200o dalam Dougal, 2005).

Coombs dan Holladay (2010) menawarkan pentingnya memahami aktivis dengan cara melihat bagaimana mereka mempersepsikan dirinya. Salah satu tokoh yang diajukan oleh Commbs dan Holladay adalah Raymond yang juga merupakan anggota dari sebuah kelompok aktivis.Raymond menyatakan bahwa aktivisme adalah tugas kemanusiaan untuk kehidupan masyarakat yang lebih baik.

Lebih lanjut ia mengatakan: activists are those whose stand up for a cause. They arise when concerns are not heard. Aktivisme dalam pandangan Raymond juga menjadi petanda sehat tidaknya demokrasi. Hal ini dikarenakan aktivis menurutnya adalah "provide insight into future values and hopes of society". Esensi dari aktivisme adalah ekspresi sesungguhnya dari kepentingan publik dalam hal partisipasi dan pembentukan masyarakat.

Raymond adalah seorang tokoh yang dinilai mampu memberikan pemikiran-pemikiran progresif dalam studi public relations khususnya isu seperti corporate sosial responsibility. Menurutnya aktivisme adalah sesuatu yang positif bagi korporasi ."Ini adalah barometer moral yang memberikan wawasan dan perhatian publik. Aktivis dapat menjadi penggerak lonceng sebagai penanda adanya perubahan sosial. Organisasi dapat berada di garda terdepan dalam pergeseran nilai sosial jika mereka mendengarkan dan bekerja dengan aktivis.

\section{SIMPULAN}

Hubungan antara aktivis dan organisasi terdapat dua jenis pendekatan.Pendekatan pertama sering disebut dengan organization centric yang melihat hubungan antara aktivis dan organisasi lebih didominasi praktek-praktek praktisi public relations yang notabene adalah representasi organisasi. Pendekatan kedua, adalah pendekatan kritis yang mulai mempertanyakan dominasi wacana dalam pendekatan organization centric.

Pendekatan postmodern sendiri berorientasi pada dua proses yakni melakukan dekonstruksi bahasa yang telah menyebabkan eksploitasi dan marjinalisasi danmendorong tindakan afirmatif melawan eksplotasi dan marjnalisasi. Oleh karena itu metode analisis yang digunakan oleh para penganut postmodern lebih banyak menggunakan analisis wacana. Untuk itu telaah kritis terhadap peran dan fungsi public aktivis dalam pendekatan postmodern lebih banyak berkaitan dengan relasi bahasa dan kekuasaan.

Pendekatan kritis melihat meskipun publik aktivis menjalankan aktivitasnya bersifat antagonistik, namun hasilnya tidak selalu destruktif/desruptif bagi organisasi. Secara umum, harus diakui bahwa pendekatan organization centric-positivis fungsionalis masih mendominasi riset dan literature public relations.

Dalam literatur yang dikuasai oleh pendekatan corporate centric-positivis fungsionalis, aktivisme pun dilihat dengan "kacamata sebelah". Aktivisme dikonstruksikan sebagai tindakan yang negatif dan destruktif mulai dari memberikan definisi dengan stigma yang negatif, membedakan dengan publik lainnya.Namun demikian konstruksi negatif publik aktivis tak bisa dipisahkan dari sejarah yang penuh konflik frontal antara organisasi dengan publik aktivis.

Mengkonstruksikan publik aktivis dengan stigma negatif justru kontraproduktif 
untuk tumbuh dan berkembangnya disiplin ilmu public relations yang masih sangat muda.Harus diakui bahwa publik aktivis juga memberikan kontribusi yang positif terhadap bidang keilmuan public relations. Oleh karenanya, diperlukan penelitian lebih lanjut yang melihat aktivisme dan kontribusi positifnya bagi organisasi (korporasi) maupun bagi public relations.

\section{DAFTAR PUSTAKA}

Botan, C. H., \& Hazleton, V. 2009. "Public relations in a New Age"dalam C. H. Botan \& V. Hazleton (Eds.), Public RelationsTheory II. New York: Routledge Taylor \& Francis Group.

Curtin, P. A., dan Gaither, T. K. 20o6. International Public Relations: Negotiating Culture, Identity, and Power. Global Public Relations and the Circuit of Culture, London: SAGE Publications, Inc.

Coombs, W.T. and Holladay, S.J. 2002. 'Helping Crisis Managers Protectreputational Assets: Initial Tests of the Situational Crisis Communication theory', Management Communication Quarterly, 16, $165^{-186 .}$

2010.PR Strategy and Application. Malden MA: Blackwell Publishing.

. 2011. "Privileging an Activist vs. a Corporate View of Public Relations History in the U.S." dalamThe Proceedings of The International History of Public Relations Conference 2011 di Bournemouth University, July 6-7.

Courtney, G and Mehta, A. 2006. "Stamping Their Ground:aStudy of Public Opinion and Activists." DalamProceedings Australian \& New Zealand Communication Association InternationalConference, 2006: Empowerment, Creativity and Innovation: Challenging Media andCommunication in the 21st Century, pages pp. 1-10, Adelaide, South Australia.

Dougall, E. 2005. “Tracking Organization-
Public Relationsships Over Time: A Framework for Longitudinal Research" dalam The Eighth International Public relationss Research Conference, March 10-13.

Dozier, D. M., \& Lauzen, M., M. 20oo.Liberating the Intellectual Domain from the Practice: Public Relations, Activism and the Role of the Scholar.Journal of Public Relations Research, Vol. 12. Number. 1, 3-22.

Grunig, J.E (Ed.). 1992.Excellence in Public Relations and Communication Management. NJ: Lawrence Erlbaum Associate Publishers

Grunig, L. A. 1992a. "Activism: How it Limits the Effectiveness of Organizations and How Excellent Public Relations Departments Respond" dalam J. E. Grunig (Ed.), Excellence in public relations and communication management (pp. 503530). Hillsdale, NJ: Lawrence Erlbaum Associates.

Heath, R. (Ed.). 2001, Handbook of Public Relations. Thousand Oaks, CA: Sage Publication.

Holtzhausen, D.R and Voto, R. 2002. "Resistance From the Margins: The Postmodern Public Relations Practitioner as Organizational Activist" Journal of Public Relations Research, Vol. 14. Number 1, 57-84.

Holtzhausen, Derina R. 2002 "Towards a Postmodern Research Agenda for Public Relations", Public Relations Review $\mathrm{Vol} 28$

Kim, J. 2009.“Anger, Efficacy, and Identity in Activism: Public Perceptions of Threat Appraisal, Attitudes, And Behavioral Intention" Disertation: University of Missouri-Columbia.

Kim, J and Sriramesh, K. 20o6. "Activism and Public Relations" dalam E. Toth (Ed), Excellence in public relations and communication management: Challenges for the next generation. Mahwah, NJ: Lawrence Erlbaum Associates Inc. 
McKie, D. 2005. "Critical Theory"dalam R. L. Heath (Ed.), Encyclopedia of Public Relations(pp. 226-228). Thousand Oaks, CA: Sage.

McKie, D., \& Munshi, D. 2007. Reconfiguring Public Relations: Ecology, Equity, and Enterprise. New York: Routledge Taylor \& Francis Group.

Taylor,M, Kent, M.LandWhite,W.J2001, "How Activist Organizations are Using the Internet to Build Relationships"Public Relationss Review.Vol. 27. 263-284. 